\title{
Influence of Different Pruning Techniques and Integrated Nutrient Management on Growth, Leaf Yield of Mulberry and its Impact on Silkworm (Bombyx mori L.) Bioassay
}

\author{
A. Thangamalar $^{1 *}$, K. Ramamoorthy ${ }^{2}$, S. Prabhu ${ }^{1}$ and P. Priyadharshini ${ }^{1}$ \\ ${ }^{1}$ Department of Sericulture, Forest College and Research Institute, TNAU, \\ Mettupalayam-641301, Tamil Nadu, India \\ ${ }^{2}$ Department of Agronomy, Horticulture Research Station, TNAU, Ooty, Tamil Nadu, India \\ *Corresponding author
}

\begin{abstract}
A B S T R A C T
Field experiments were carried out during Kharif and Rabi seasons of two years at the Department of Sericulture, Tamil Nadu Agricultural University, Coimbatore to study the influence of different pruning heights in mulberry and integrated nutrient management (INM) practices on growth, leaf and cocoon productivity as well as profitability in mulberry. The experiments were laid out in a strip plot design with three main plot treatments and six sub plot treatments replicated thrice. The results revealed that middle pruning ( $90 \mathrm{~cm}$ height) technique had positive impact on mulberry growth parameters such as less intermodal length with significantly high shoot length, number of branches per plant during both kharif and rabi seasons of the respective years. Further, the yield attributes viz., leaf dry weight, 100 leaves weight, leaf yield per plant and leaf yield/ha/harvest were also significantly higher in middle pruning technique. Among the integrated nutrient management practices, $50 \%$ organic $+50 \%$ inorganic fertilizers $\left(\mathrm{M}_{2}\right)$ application showed significantly better mulberry growth and yield parameters. The same treatment contributed significantly higher silkworm economical parameters viz., larval weight, cocoon weight, shell weight, shell ratio and ERR per cent in both the seasons. The mean economics of mulberry leaves production and silkworm cocoon production were enhanced with higher B: C ratio of 2.76, 2.16 in mulberry and 2.70, 2.06 in silkworm, respectively, during kharif and rabi.
\end{abstract}

Keywords

Mulberry, Pruning, INM, Growth and

Yield attributes,

Economics of

Sericulture

Article Info

Accepted:

26 January 2018

Available Online:

10 February 2018

\section{Introduction}

Mulberry leaf is the sole food material and its nutrition is necessary for growth regulating factors in silkworm, Bombyx mori L. Silkworm derives proteins directly from the mulberry leaves for producing nearly 70 per cent of silk. Hence, the mulberry leaves should be produced in abundant quantity with good quality and reasonable cost of production. Unpruned mulberry plant was found to produce less quantity of leaves with poor quality. Periodic pruning is important to maintain vigorous young shoots and foliage 
with proper nutrients. In irrigated condition, where intensive cultivation is carried out, it is necessary to prune the plants to maintain their peak production. The leaf yield varied with changes in the pruning heights e.g. progressive and significant decrease in leaf yield with the increase in number of shoot pruning at the ground level. Now-a-days, mostly the farmers take up bottom pruning at frequent intervals with shoot harvest i.e., 5-6 times per year for continuous silkworm rearing. Consequent to severe pruning, the crop fails to produce more biomass and requires large quantities of nutrients for regeneration. This practice has directly or indirectly affected the soil fertility and plant growth rate. Hence, the pruning height affects the rate of plant growth, quality and quantity of mulberry leaves.

Mulberry leaf productivity is highly dependent on plant nutrients such as nitrogen, phosphorous and potassium and is known to respond well to the addition of organic manures (Jaiswal et al., 2005). The chemical fertilizers are becoming costlier in recent times due to escalating costs and scarce availability of commodities. The highly intensive mulberry cropping system causes depletion of nutrients in soil and excess usage of inorganic fertilizers causes deleterious effect on soil health. During mulberry cultivation and rearing of silkworm, enormous amount of farm and rearing residue is converted into sericompost (Bhogesha et al., 2005) and it can be done by using effective microorganisms (EMO). When it is mixed with organic manure, the beneficial microbes proliferate fermenting the waste into nutrient rich organic manure and antioxidant rich compost. Ram Rao et al., (2007) proved the influence of VAM fungi and bacterial biofertilizer with reduction of recommended dose of nitrogen and phosphorous on leaf quality traits of mulberry and growth of silkworm. With the above ideas, the present investigation was carried out with different pruning techniques coupled with integrated nutrient management (INM) practices which are bound to have significant effect on growth, physiological parameters with enhanced quality leaf productivity and economics.

\section{Materials and Methods}

Field experiments were conducted during kharif and Rabi seasons of two years (four rearings) at Department of Sericulture, Tamil Nadu Agricultural University, Coimbatore to study the effect of different pruning heights and INM practices on growth, leaf yield and cocoon productivity and economics in mulberry. The experiments were laid out in a strip plot design with eighteen treatment combinations and replicated thrice. The main plot treatments comprised of pruning techniques (M) viz., $\mathrm{M}_{1}$ - Bottom Pruning (height of $30 \mathrm{~cm}$ ); $\mathrm{M}_{2}$ - Middle pruning (height of $90 \mathrm{~cm}$ ) $\mathrm{M}_{3}$ - Top pruning (height of $150 \mathrm{~cm}$ ) and the subplot treatments $(\mathrm{S})$ viz., $\mathrm{S}_{1}$ - Absolute control; $\mathrm{S}_{2}$ - Organics 100\% alone (vermicompost@2 tons/ha/yr + Seriwaste compost (Sericultural waste composted by using Effective Microorganisms) @ 2 tons/ha/yr + Biomix, which is a mixture of Azospirillum (20 kg ha $\left.{ }^{-1} \mathrm{year}^{-1}\right)+$ VAM (200 $\mathrm{kg} \mathrm{ha}^{-1}$ year $\left.^{-1}\right)+$ Phospho bacteria $\left(10 \mathrm{~kg} \mathrm{ha}^{-1}\right.$ year $^{-1}$ ) with zinc enriched FYM @ 2 tons ha ${ }^{-}$ ${ }^{1}$ year $^{-1}$ ); $\mathrm{S}_{3}$ - Organics 75\% + inorganics 25\%; $\mathrm{S}_{4}$ - Organics $50 \%$ + inorganics $50 \% ; \mathrm{S}_{5}-$ Organics $25 \%+$ inorganics $75 \%$ and $\mathrm{S}_{6^{-}}$ Inorganics $100 \%$ (Recommended dose of $\mathrm{N}$ $375 \mathrm{~kg}$ in the form of urea, $\mathrm{P} 140 \mathrm{Kg}$ in the form of $\mathrm{P}_{2} \mathrm{O}_{5}, \mathrm{~K} 140 \mathrm{~kg}$ in the form of $\mathrm{K}_{2} \mathrm{O}$, $\mathrm{Zn} 25 \mathrm{~kg}$ in the form of $\mathrm{Zn} \mathrm{So}_{4} \mathrm{ha}^{-1}$ ).

Already established mulberry garden with V1 variety was used as test crop at spacing of $90 \mathrm{x}$ $90 \mathrm{~cm}$. The soil of the experimental field was sandy clay loam in texture. The experimental soil was low in available nitrogen $\left(261 \mathrm{~kg} \mathrm{ha}^{-}\right.$ $\left.{ }^{1}\right)$, medium in available phosphorous (12 $\mathrm{Kg}$ $\mathrm{ha}^{-1}$ ) and high in available potash $(450 \mathrm{Kg}$ ha 
$\left.{ }^{1}\right)$ and adequate amount of micro nutrients viz., Copper $(0.75 \mathrm{ppm})$, Iron (6.31 ppm), Manganese $(2.11 \mathrm{ppm})$ and Zinc $(1.05 \mathrm{ppm})$. A total quantity of $801.1 \mathrm{~mm}$ rainfall was received in 42 rainy days during the period of investigations. Observations on growth and physiological parameters, leaf yield of mulberry and cocoon parameters are recorded during the course of investigation. Economics was also worked out for different treatment combinations.

\section{Results and Discussion}

\section{Growth attributes of mulberry}

Growth parameters of mulberry were influenced significantly by pruning techniques and INM practices in kharif and rabi seasons of two years (Table 1). Middle pruning $\left(\mathrm{M}_{2}\right)$ had significantly less inter nodal length (5.3 $\mathrm{cm})$ in kharif and top pruning $\left(\mathrm{M}_{3)}(6.6 \mathrm{~cm})\right.$ in rabi. INM practices of 50 per cent organic and 50 per cent inorganic fertilizer gave significantly less intermodal length of 5.4 and $6.3 \mathrm{~cm}$ in kharif and rabi respectively. The interaction effect was significantly higher in the treatment of $\mathrm{M}_{2} \mathrm{~S}_{4}$ which registered less value of 5.4 and $6.6 \mathrm{~cm}$ in the respective seasons. Among the seasons, the inter nodal length was low in kharif. It might be due the reason of high sunlight and temperature prevailed during the kharif which resulted in shorter shoot length noticed in these treatments, which resulted in short internode and thereby accommodated more number of leaves. Chiranth (2009) noticed similar findings in mulberry cultivation with combined application of inorganic and biofertilizer in mulberry based inter cropping system. Sridhara et al., (1995) established a positive association between internodal distances due to inorganic and organic.

Middle pruning along with 50 per cent organic and 50 per cent inorganic fertilizer $\left(\mathrm{M}_{2} \mathrm{~S}_{4}\right)$ recorded higher shoot length and number of leaves per plant in both seasons except in number of branches, and leaf area Index (LAI). Number of branches was significantly higher in top pruning during kharif followed by middle pruning. LAI has no significant effect during rabi. The interaction effect of both practices, pruning and INM practiced in middle pruning $\left(\mathrm{M}_{2}\right)$ with $50 \%$ organic and $50 \%$ inorganic fertilizer application $\left(\mathrm{S}_{4}\right)$ registered increased internodal length, shoot length, number of branches per plant, number of leaves per plant, LAI. The enhancement of leaf area due to Azospirillum, Azotobacter and Phosphobacterium application in mulberry was reported earlier by Das et al., (1992).

\section{Yield parameters and leaf yield of mulberry}

Mulberry leaf yield parameters recorded during both kharif and rabi seasons of two years significantly differed due to treatments (Table 2). In main plot, middle pruning technique $\left(\mathrm{M}_{2}\right)$ showed significantly higher mean leaf dry weight (260 and $255 \mathrm{~g}$ ), 100 leaves weight (400 and $467 \mathrm{~g}$ ), leaf yield per plant (941.5 and $1060 \mathrm{~g}$ ) and leaf yield per hectare per harvest (11798 and $12641 \mathrm{~kg}$ ) during kharif and rabi, respectively. In sub plot, $50 \%$ organic fertilizers $+50 \%$ inorganic fertilizer $\left(S_{4}\right)$ showed significantly higher yield parameters in both the seasons followed by $25 \%$ organic $+75 \%$ inorganic fertilizers $\left(\mathrm{S}_{5}\right)$ application. During both the seasons, the interaction effect showed in middle pruning with $50 \%$ organic $+50 \%$ inorganic fertilizer $\left(\mathrm{M}_{2} \mathrm{~S}_{4}\right)$ in almost all the yield attributes except leaf dry weight, there was no interaction effect during kharif season. More studies were support to this present study, Chiranth (2009) noticed that combined application of inorganic fertilizers and bio fertilizers enhanced mulberry leaf yield. Susheelamma et al., (2004) reported that the leaf yield during rainy season was higher under in situ organic farming when compared to control. 
Table.1 Effect of pruning techniques and integrated nutrient management practices on growth parameters of mulberry during kharif and rabi seasons (Mean data of two years)

\begin{tabular}{|c|}
\hline Treatment \\
\hline Main plot \\
\hline$M_{1}-$ Bottom pruning \\
\hline $\mathrm{M}_{2}-$ Middle pruning \\
\hline$M_{3}-$ Top pruning \\
\hline SEd \\
\hline $\mathrm{CD}(\mathrm{P}=0.05)$ \\
\hline Sub plot \\
\hline$S_{1}-$ Absolute control \\
\hline $\mathbf{S}_{2}$ - Organics $100 \%$ \\
\hline$S_{3}-$ Organics $75 \%+$ inorganics $25 \%$ \\
\hline $\mathrm{S}_{4}-$ Organics $50 \%+$ inorganics $50 \%$ \\
\hline$S_{5}-$ Organics $25 \%+$ inorganics $75 \%$ \\
\hline $\mathrm{S}_{6}-$ Inorganics $100 \%$ \\
\hline SEd \\
\hline $\mathrm{CD}(\mathrm{P}=0.05)$ \\
\hline
\end{tabular}

\begin{tabular}{|c|c|c|c|c|c|c|c|c|c|}
\hline \multicolumn{2}{|c|}{ Inter nodal length (cm) } & \multicolumn{2}{|c|}{ Shoot length (cm.) } & \multicolumn{2}{|c|}{$\begin{array}{c}\text { Number of } \\
\text { branches/plant }\end{array}$} & \multicolumn{2}{|c|}{ Number of leaves/plant } & \multicolumn{2}{|c|}{ Leaf area Index } \\
\hline Kharif & Rabi & Kharif & Rabi & Kharif & Rabi & Kharif & Rabi & Kharif & Rabi \\
\hline 6.3 & 7.0 & 107 & 113 & 12 & 21 & 223 & 280 & 3.4 & 5.8 \\
\hline 5.9 & 6.6 & 123 & 124 & 14 & 22 & 246 & 291 & 3.9 & 6.6 \\
\hline 5.3 & 6.7 & 104 & 112 & 13 & 26 & 236 & 264 & 3.4 & 5.3 \\
\hline 0.1 & 0.1 & 5.1 & 3.04 & 0.39 & 1.75 & 7 & 8 & 0.2 & 0.3 \\
\hline 0.2 & 0.2 & 12.5 & 7.4 & 1.0 & 4.3 & 18 & NS & NS & 0.7 \\
\hline 6.5 & 7.5 & 102 & 98 & 10 & 16 & 143 & 182 & 1.7 & 3.0 \\
\hline 5.8 & 6.5 & 105 & 110 & 13 & 21 & 207 & 239 & 2.8 & 4.4 \\
\hline 5.5 & 6.6 & 110 & 115 & 14 & 23 & 240 & 275 & 3.6 & 5.5 \\
\hline 5.4 & 6.3 & 128 & 132 & 16 & 28 & 305 & 363 & 5.2 & 9.1 \\
\hline 6.0 & 6.7 & 114 & 126 & 14 & 25 & 266 & 317 & 4.5 & 7.0 \\
\hline 5.7 & 7.0 & 110 & 118 & 14 & 24 & 247 & 294 & 3.5 & 6.0 \\
\hline 0.1 & 0.1 & 5.1 & 2 & 0.2 & 1.1 & 6 & 8 & 0.2 & 0.3 \\
\hline 0.2 & 0.2 & 13 & 4 & 1 & 3 & 14 & 20 & 0.5 & 0.8 \\
\hline
\end{tabular}

NS - Non significant

Table.2 Effect of pruning techniques and integrated nutrient management practices yield parameters and leaf yield of mulberry during kharif and rabi seasons (Mean data of two years)

\begin{tabular}{|c|}
\hline Treatment \\
\hline Main plot \\
\hline $\mathrm{M}_{1}-$ Bottom pruning \\
\hline $\mathrm{M}_{2}$ - Middle pruning \\
\hline$M_{3}-$ Top pruning \\
\hline SEd \\
\hline $\mathrm{CD}(\mathrm{P}=0.05)$ \\
\hline Sub plot \\
\hline$S_{1}-$ Absolute control \\
\hline $\mathrm{S}_{2}-$ Organics $100 \%$ \\
\hline$S_{3}$ - Organics $75 \%+$ inorganics $25 \%$ \\
\hline $\mathrm{S}_{4}-$ Organics $50 \%+$ inorganics $50 \%$ \\
\hline$S_{5}-$ Organics $25 \%+$ inorganics $75 \%$ \\
\hline$S_{6}-$ Inorganics $100 \%$ \\
\hline SEd \\
\hline $\mathrm{CD}(\mathrm{P}=\mathbf{0 . 0 5})$ \\
\hline
\end{tabular}

\begin{tabular}{|c|c|c|c|c|c|c|c|}
\hline \multicolumn{2}{|c|}{ Leaf dry weight (g) } & \multicolumn{2}{|c|}{100 leaves weight (g) } & \multicolumn{2}{|c|}{ Leaf yield per plant (g) } & \multicolumn{2}{|c|}{ Leaf yield (kg /ha/harvest } \\
\hline Kharif & Rabi & Kharif & Rabi & Kharif & Rabi & Kharif & Rabi \\
\hline 198 & 207 & 336 & 378 & 778.2 & 817.7 & 9802 & 10178 \\
\hline 260 & 255 & 400 & 467 & 941.5 & 1060.0 & 11826 & 12641 \\
\hline 241 & 206 & 392 & 345 & 860.5 & 874.0 & 10598 & 10651 \\
\hline 8 & 7.6 & 3.8 & 4.4 & 25.8 & 48.1 & 195 & 226 \\
\hline 20 & 18.5 & 9 & 10.7 & 63.2 & 117.8 & 478 & 553 \\
\hline 137 & 127 & 342 & 354 & 487.7 & 565.4 & 6187 & 7147 \\
\hline 206 & 188 & 356 & 395 & 758.5 & 813.4 & 9419 & 10041 \\
\hline 247 & 224 & 372 & 401 & 885.5 & 945.3 & 11221 & 11448 \\
\hline 300 & 285 & 415 & 423 & 1238.8 & 1189.8 & 14098 & 14521 \\
\hline 268 & 262 & 398 & 411 & 954.1 & 1050.7 & 12888 & 12749 \\
\hline 241 & 249 & 373 & 395 & 835.8 & 938.7 & 10636 & 11033 \\
\hline 6.9 & 4.9 & 5.3 & 7.2 & 15.4 & 23.4 & 236 & 134 \\
\hline 16.8 & 12.1 & 13 & 17.6 & 37.7 & 57.1 & 578 & 327 \\
\hline
\end{tabular}


Table.3 Effect of pruning techniques and Integrated Nutrient Management practices on silkworm economical parameters during kharif and rabi seasons (Mean data of two years)

\begin{tabular}{|c|c|c|c|c|c|c|c|c|c|c|}
\hline \multirow[t]{2}{*}{ Treatment } & \multicolumn{2}{|c|}{$\begin{array}{l}\text { Larval weight } \\
\text { (g.) }\end{array}$} & \multicolumn{2}{|c|}{$\begin{array}{l}\text { Cocoon weight } \\
\text { (g.) }\end{array}$} & \multicolumn{2}{|c|}{$\begin{array}{l}\text { Shell weight } \\
\text { (g.) }\end{array}$} & \multicolumn{2}{|c|}{ Shell ratio $(\%)$} & \multicolumn{2}{|c|}{$\operatorname{ERR}(\%)$} \\
\hline & Kharif & $R a b i$ & Kharif & Rabi & Kharif & Rabi & Kharif & $R a b i$ & Kharif & $R a b i$ \\
\hline \multicolumn{11}{|l|}{ Main plot } \\
\hline$M_{1}-$ Bottom pruning & 3.2 & 3.9 & 1.54 & 1.84 & 0.33 & 0.39 & 20.86 & 20.66 & 91.8 & 96.8 \\
\hline $\mathbf{M}_{2}-$ Middle pruning & 3.3 & 4.0 & 1.66 & 1.99 & 0.35 & 0.42 & 21.05 & 20.73 & 91.7 & 97.4 \\
\hline$M_{3}-$ Top pruning & 3.1 & 3.9 & 1.59 & 1.83 & 0.33 & 0.39 & 20.53 & 21.01 & 91.5 & 97.1 \\
\hline SEd & 0.08 & 0.08 & 0.03 & 0.04 & 0.01 & 0.01 & 0.43 & 0.32 & 0.95 & 0.21 \\
\hline $\mathrm{CD}(\mathrm{P}=0.05)$ & 0.18 & NS & 0.07 & 0.06 & 0.03 & 0.03 & NS & NS & NS & 0.52 \\
\hline \multicolumn{11}{|l|}{ Sub plot } \\
\hline $\mathbf{S}_{1}-$ Absolute control & 2.8 & 3.5 & 1.59 & 1.78 & 0.30 & 0.36 & 19.07 & 19.37 & 88.6 & 95.4 \\
\hline$S_{2}-$ Organics $100 \% *$ & 3.0 & 3.9 & 1.63 & 1.91 & 0.33 & 0.39 & 19.90 & 20.68 & 90.3 & 97.0 \\
\hline $\begin{array}{l}S_{3}-\text { Organics } 75 \%+\text { inorganics } \\
25 \%\end{array}$ & 3.2 & 4.0 & 1.65 & 1.90 & 0.36 & 0.41 & 21.26 & 20.37 & 93.6 & 97.2 \\
\hline $\begin{array}{l}\mathrm{S}_{4}-\text { Organics } 50 \% \text { + inorganics } \\
50 \%\end{array}$ & 3.6 & 4.2 & 1.63 & 2.02 & 0.37 & 0.44 & 22.65 & 22.33 & 94.5 & 98.3 \\
\hline $\begin{array}{l}S_{5}-\text { Organics } 25 \%+\text { inorganics } \\
75 \%\end{array}$ & 3.3 & 4.1 & 1.55 & 1.83 & 0.34 & 0.40 & 21.13 & 20.72 & 91.4 & 97.5 \\
\hline$S_{6}$ - Inorganics $100 \% * *$ & 3.2 & 4.0 & 1.54 & 1.89 & 0.33 & 0.41 & 20.89 & 21.34 & 91.6 & 97.1 \\
\hline SEd & 0.03 & 0.08 & 0.02 & 0.02 & 0.01 & 0.00 & 0.45 & 0.42 & 0.79 & 0.52 \\
\hline $\mathrm{CD}(\mathrm{P}=0.05)$ & 0.07 & 0.19 & 0.06 & 0.05 & 0.02 & 0.01 & 1.10 & 1.02 & 1.94 & 0.35 \\
\hline
\end{tabular}


Table.4 Effect of pruning techniques and Integrated Nutrient Management on economics of mulberry and silkworm during kharif and rabi seasons (Mean data of two years)

\begin{tabular}{|c|c|c|c|c|c|c|c|c|c|c|c|c|}
\hline \multirow[t]{3}{*}{ Treatment } & \multicolumn{6}{|c|}{ Mulberry } & \multicolumn{6}{|c|}{ Silkworm } \\
\hline & \multicolumn{3}{|c|}{ Kharif } & \multicolumn{3}{|c|}{ Rabi } & \multicolumn{3}{|c|}{ Kharif } & \multicolumn{3}{|c|}{ Rabi } \\
\hline & $\begin{array}{l}\text { Gross } \\
\text { return }\end{array}$ & $\begin{array}{c}\text { Net } \\
\text { return }\end{array}$ & $\begin{array}{l}\mathrm{B}: \mathrm{C} \\
\text { ratio }\end{array}$ & $\begin{array}{l}\text { Gross } \\
\text { return }\end{array}$ & $\begin{array}{c}\text { Net } \\
\text { return }\end{array}$ & $\begin{array}{l}\text { B:C } \\
\text { ratio }\end{array}$ & $\begin{array}{l}\text { Gross } \\
\text { return }\end{array}$ & $\begin{array}{c}\text { Net } \\
\text { return }\end{array}$ & $\begin{array}{l}\mathrm{B}: \mathrm{C} \\
\text { ratio }\end{array}$ & $\begin{array}{l}\text { Gross } \\
\text { return }\end{array}$ & $\begin{array}{c}\text { Net } \\
\text { return }\end{array}$ & $\begin{array}{l}\text { B:C } \\
\text { ratio }\end{array}$ \\
\hline $\mathbf{M}_{1} \mathbf{S}_{1}$ & 12350 & 1103 & 0.99 & 17324 & 4839 & 1.73 & 39011 & 11567 & 1.42 & 39525 & 12081 & 1.44 \\
\hline $\mathrm{M} \mathrm{S}_{2}$ & 20378 & 1884 & 1.03 & 21039 & 8247 & 1.22 & 42028 & 14584 & 1.53 & 55195 & 27751 & 2.01 \\
\hline $\mathrm{M}_{1} \mathrm{~S}_{3}$ & 25026 & 6256 & 1.25 & 24406 & 10945 & 1.39 & 47410 & 19966 & 1.73 & 55842 & 28398 & 2.03 \\
\hline $\mathrm{M}_{1} \mathrm{~S}_{4}$ & 36151 & 17105 & 1.78 & 35341 & 19577 & 1.98 & 55261 & 27817 & 2.01 & 65187 & 37743 & 2.38 \\
\hline $\mathbf{M}_{1} \mathbf{S}_{5}$ & 29328 & 10005 & 1.43 & 30886 & 15471 & 1.71 & 46623 & 19179 & 1.70 & 56267 & 28823 & 2.05 \\
\hline $\mathrm{M}_{1} \mathrm{~S}_{6}$ & 23793 & 4193 & 1.14 & 23671 & 9602 & 1.29 & 46946 & 19502 & 1.71 & 56208 & 28764 & 2.05 \\
\hline $\mathrm{M}_{2} \mathrm{~S}_{1}$ & 17387 & 6799 & 1.47 & 20657 & 11759 & 2.21 & 45145 & 17701 & 1.64 & 45499 & 18055 & 1.66 \\
\hline $\mathrm{M}_{2} \mathrm{~S}_{2}$ & 26559 & 8725 & 1.39 & 28651 & 14729 & 1.73 & 51335 & 23891 & 1.87 & 58168 & 30724 & 2.12 \\
\hline $\mathrm{M}_{2} \mathrm{~S}_{3}$ & 31816 & 13706 & 1.64 & 34127 & 18700 & 2.02 & 54123 & 26679 & 1.97 & 67515 & 40071 & 2.46 \\
\hline $\mathrm{M}_{2} \mathrm{~S}_{4}$ & 42349 & 23963 & 2.16 & 39975 & 23028 & 2.33 & 56667 & 29223 & 2.06 & 74006 & 46562 & 2.70 \\
\hline $\mathrm{M}_{2} \mathrm{~S}_{5}$ & 34298 & 15635 & 1.72 & 34756 & 19332 & 1.99 & 49150 & 21706 & 1.79 & 59916 & 32472 & 2.18 \\
\hline $\mathrm{M}_{2} \mathrm{~S}_{6}$ & 31642 & 12702 & 1.57 & 31450 & 16127 & 1.78 & 46243 & 18799 & 1.69 & 65369 & 37925 & 2.38 \\
\hline $\mathrm{M}_{3} \mathrm{~S}_{1}$ & 15835 & 4917 & 1.30 & 15618 & 7314 & 1.61 & 35689 & 8245 & 1.30 & 39293 & 11849 & 1.43 \\
\hline $\mathrm{M}_{3} \mathrm{~S}_{2}$ & 24541 & 6376 & 1.26 & 25617 & 12581 & 1.51 & 46115 & 18671 & 1.68 & 52032 & 24588 & 1.90 \\
\hline $\mathrm{M}_{3} \mathrm{~S}_{3}$ & 27318 & 8878 & 1.39 & 27328 & 13665 & 1.59 & 53463 & 26019 & 1.95 & 55328 & 27884 & 2.02 \\
\hline $\mathrm{M}_{3} \mathrm{~S}_{4}$ & 38482 & 19766 & 1.93 & 33594 & 18535 & 1.92 & 55250 & 27806 & 2.01 & 62668 & 35224 & 2.28 \\
\hline $\mathrm{M}_{3} \mathrm{~S}_{5}$ & 35953 & 16960 & 1.78 & 29977 & 15517 & 1.69 & 46074 & 18630 & 1.68 & 53892 & 26448 & 1.96 \\
\hline $\mathbf{M}_{3} \mathbf{S}_{6}$ & 31838 & 12568 & 1.55 & 27627 & 13637 & 1.53 & 43753 & 16309 & 1.59 & 50715 & 23271 & 1.85 \\
\hline
\end{tabular}

\# - Data not statistically analyzed 
Fig.1 Interaction effect of pruning techniques and Integrated Nutrient Management on cocoon yield for two seasons (Mean values of two years)

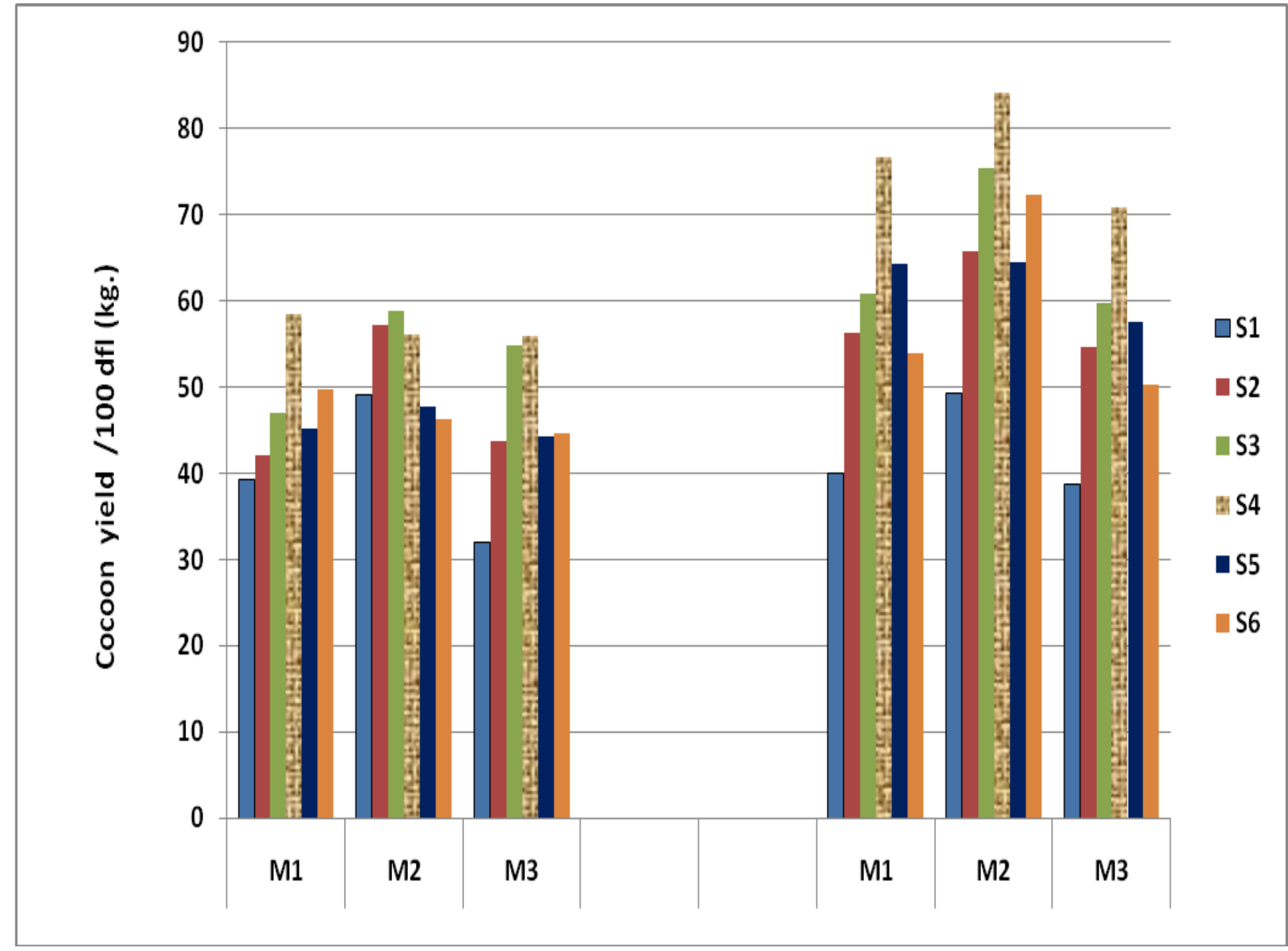




\section{Economical parameters of silkworm}

Effect of pruning and INM practices were found significant on silkworm economical parameters during kharif and rabi seasons of two years (Table 3 ). Silkworm larval weight (33 and $40 \mathrm{~g}$ ), cocoon weight (1.66 and 1.99 $\mathrm{g})$, shell weight $(0.35$ and $0.42 \mathrm{~g})$ were significantly higher during kharif and rabi, respectively. The pruning techniques had no significant effect on shell ratio during both seasons and effective rearing rate (ERR\%) during kharif. Application of 50\% organic + $50 \%$ inorganic fertilizers $\left(\mathrm{S}_{4}\right)$ was found significant effect on all economical parameters of silkworm in the irrespective of the seasons. During the kharif season, the cocoon weight was significantly higher under $75 \%$ organic $+25 \%$ inorganic fertilizer application treatment $\left(\mathrm{S}_{3}\right)$. The silkworm cocoon yield per hundred disease free layings (dfls) the interaction effect was found in middle pruning with $50 \%$ organic $+50 \%$ inorganic fertilizer application $\left(\mathrm{M}_{2} \mathrm{~S}_{4}\right)$ during kharif season (Fig. 1). Philomena et al., (2003) have observed higher ERR in silkworms fed on mulberry leaves which were grown by applying lower dose of inorganic fertilizer and higher dose of organic manures.

\section{Economics of mulberry and silkworm}

Economics of mulberry leaf production and silkworm rearing was estimated during kharif and rabi seasons of two years (Table 4). Gross return, net return and $\mathrm{B}: \mathrm{C}$ ratio of Rs.42349, Rs.23963 and 2.16 in kharif; Rs. 39975, Rs.23985 and 2.33 in rabi seasons under the mulberry cultivation and Rs.56667, Rs.29223 and 2.06 in kharif; Rs.74006, Rs.46562 and 2.70 in rabi for silkworm rearing showed higher in middle pruning with $50 \%$ organic $+50 \%$ inorganic fertilizer application $\left(\mathrm{M}_{2} \mathrm{~S}_{4}\right)$. Chiranth (2009) also noticed $100 \%$ recommended dose of fertilizer had higher gross returns but comparatively lower B: C ratio (1.78) than biofertilizers (Azophos $+50 \%$ cut in nitrogen and phosphorous fertilizers) applied mulberry which recorded the higher B: C ratio 2.07.

Thus from the present study it may be concluded that middle pruning along with integrated nutrient management practice of application of 50 per cent organic and 50 per cent recommended dose of inorganic fertilizers are found optimum for mulberry higher growth and yield attributes, yield economics of mulberry and silkworm with enhanced net return and $\mathrm{B}$ : $\mathrm{C}$ ratio in both kharif and rabi under irrigated condition.

\section{References}

Bhogesha, K., Das, P. K., Vedavyasa, K., Chowdary, N. B. and Rajanna, L. 2005. Evaluation of different methods of composting by recycling seri farm residues (Lead paper). In: National seminar on composting and vermicomposting, Central Sericultural Research and Training Institute, Mysore (26-27 October), 111-115.

Chandrashekar, D. S. Shekar Shetty, H. and Datta, R. K. 1996. Effect of inoculation with Acaulo sporalaeis, Bacillus megatherium var. phosphaticum and Azospirillum brasillance using two sources of phosphorous on growth and yield of mulberry. Sericologia. 36: 283287.

Chiranth, C. R. 2009. Studies on combined influence of inorganics and biofertilizers in mulberry based intercropping systems and their impact on silkworm bioassay. M.Sc., Thesis. Tamil Nadu Agricultural University, Coimbatore, 126p.

Das, P. K., Ghosh, A., Ramakhant. P. C., Choudhury and Datta, R. K. 1992. Response of different mulberry cultivars to Azotobacter biofertilizer under 
irrigated condition. National Conference on Sericultural Research, December, 10-11.

Jaiswal, K., Goel, R., Singh, S., Kumar, R. and Gupta, S. 2005. Influence of different organic manures on few traits of Mulberry and silk cocoons under Lucknow Condition, Progress of Research in Organic Sericulture and Seri-Byproduct Utilization. Seri Scientific Publishers, Bangalore, 127130.

Philomena, K. L., Subramanayam, M. R., Jagadeesh, N. and Kamble, C. K. 2003. Qualitative and quantitative analysis of varieties as influenced by using organic manure (compost) and inorganic fertilizers for production of quality seed cocoons. Proc. Natl. Sem. Silkworm Seed Prodn, SSTL, Bangalore, 69 - 74.
Ram Rao, D. M., Kodandaramaiah, J., Reddy, M. P., Katiyar, R. S. and Rahmathulla, V. K. 2007. Effect of VAM fungi and bacterial biofertilizers on mulberry leaf quality and silkworm cocoon characters under semiarid conditions. Caspian Journal of Environmental Science. 5(2): 111-117.

Sridhara, S., Sivakumar, H. R. and Doraiswamy. 1995. Mulberry leaf yield and nitrogen application. Indian silk. 34(2): 23-24.

Susheelamma, B. N., Dandin, S. B., Kamble, C. K. and Prithvi, R. U. 2004. Studies on in situ organic farming for efficient water conservation and soil fertility management under dry farming mulberry. Sericologia. 44(1):71-77.

\section{How to cite this article:}

Thangamalar, A., K. Ramamoorthy, S. Prabhu and Priyadharshini, P. 2018. Influence of Different Pruning Techniques and Integrated Nutrient Management on Growth, Leaf Yield of Mulberry and Its Impact on Silkworm (Bombyx mori L.) Bioassay. Int.J.Curr.Microbiol.App.Sci. 7(02): 2963-2971. doi: https://doi.org/10.20546/ijcmas.2018.702.360 